tude of the westerlies between September 9 and 12 (fig. 3). The latter circumstance occurred in consonance with retrogression of the blocking anticyclone from near the United Kingdom to a position south of Iceland during this period. As a result the depressed westerlies in the eastern Atlantic swept hurricane Flora rapidly northeastward.

Hurricane Gracie, on the other hand, had its inception in the ascendant phase of the index. Thus the westerlies were increasing their latitudinal separation from the storm, and it drifted slowly northwestward. Around the time of the index maximum, from the 25 th to the $27 \mathrm{th}$, the hurricane wallowed indecisively while blocked by a High which moved eastward across New England. The hurricane resumed its northwestward course toward the coast on the 27 th as the High center moved east of the storm's meridian. This was also about the time hurricane Hannah put in its appearance about 1400 miles farther east. Between October 1 and 2 both Gracie (now an extratropical Low), and hurricane Hannah recurved sharply eastward as the index dropped below the normal.

Thus it appears that the Atlantic hurricanes this month were spawned when the speed of the temperate westerlies (and the subtropical easterlies) was above normal, at which time westward motion prevailed. When the zonal index declined below the normal, eastward motion and/or recurvature to eastward occurred.

\section{PACIFIC}

In the North Pacific, 12 tropical cyclones were observed this September. In the eastern Pacific, two hurricanes developed off the west coast of Mexico, and one tropical storm occurred east of Hawaii. The first eastern Pacific hurricane (fig. 8) was detected near $14^{\circ} \mathrm{N}$., $98^{\circ} \mathrm{W}$. on September 4 , about the time the index rose above the normal. It apparently disintegrated over Baja California on the 11 th when the index was dropping sharply. The second hurricane (not shown) was detected near $17^{\circ} \mathrm{N}$, $119^{\circ} \mathrm{W}$. on the 21 st and, after following an irregular path, apparently dissipated on the 26 th near $20^{\circ} \mathrm{N}$., $130^{\circ} \mathrm{W}$.

Tropical storm Wanda, east of Hawaii, was shortlived, as was tropical storm Opal and depressions Marge, Ruth, and Thelma (not shown). Tropical storm Nora (Sept. 5-12) moved from east of the Phillipines across Luzon and passed near Hong Kong into the Yellow Sea (fig. 8). Highest winds were estimated at about 35 knots.

In addition to typhoon Patsy in the central Pacific, and typhoon Louise which developed late in August but hit Formosa early in September, two other severe typhoons. wreaked widespread destruction in the Far East. These were typhoon Sarah and typhoon Vera, whose tracks are shown in figure 8 .

Typhoon Sarah, first detected on September 11, reached typhoon intensity on the 12th, passed over the Ryukyus. on the 15th, and swept across southern Korea into the Sea of Japan. Winds well over 100 knots brought considerable destruction to Korea and southern Japan, and heavy casualties in the fishing fleets.

About 10 days later typhoon Vera, a monstrous storm in both size and intensity, after originating near the Marianas, moved northwestward and then northward along the $135^{\circ} \mathrm{E}$. meridian, striking central Honshu on the $26 \mathrm{th}$. Winds well over 100 knots plus excessive precipitation and tides resulted in enormous casualties and destruction, placing it in the category of one of the greatest natural catastrophies in the modern history of Japan.

\section{REFERENCE}

1. J. Namias "Long Range Factors Affecting the Genesis and Paths: of Tropical Cyclones," Proceedings of the UNESCO Symposium. on Typhoons, 9-12 November 1954, Tokyo, pp. 213-219.

\title{
Weather Note
}

\section{A REPORTED SEA LEVEL PRESSURE OF 877 MB.}

\author{
C. L. JORDAN \\ Florida State University, Tallahassee, Fla. \\ [Manuscript received September 8, 1959; revised September 14, 1959]
}

A dropsonde observation made in the eye of typhoon Ida at approximately $0500 \mathrm{GMT}$, September 24,1958 showed a sea level pressure of $877 \mathrm{mb}$. (25.91 in.) which is believed to be the lowest sea level pressure ever recorded., ${ }^{1,2}$ This is about $10 \mathrm{mb}$. lower than the generally accepted mini-

1 The value of $873 \mathrm{mb}$. reported for this typhoon in the 1958 Climatological Data-National Summary (p. 93) represents an estimate of the sea level pressure based on the last reported information from the dropsonde. The pressure-height computation from this sounding, which was made 8 hours earlier than the one considered in this note, gave 878 mb. as the sea level pressure.

2 Spectacular photographs of the eye of this storm taken from very high levels have been presented by Bundgaard, Fletcher, and Smith [1]. mum pressure of $26.185 \mathrm{in}$. ( $886.7 \mathrm{mb}$.) which was observed in a typhoon in 1927 by the steamship Sapoeroea east of the Philippines, and about $15 \mathrm{mb}$. lower than the lowest: Western Hemisphere reading of $26.35 \mathrm{in}$. (892.3 mb.) which was observed at Lower Matecumbe Key during the Florida Keys hurricane of September 1935 (cf. [2]).

The dropsonde observation cited above was made from the 700-mb. level by a U.S. Air Force reconnaissance aircraft of the 54th Weather Reconnaissance Squadron. At. the time of this observation, typhoon Ida was located. 
TABLE 1.-Pressure-height, temperature, and dewpoint data for standard and significant levels in the dropsonde observation made in the eye of typhoon Ida at 0500 GMT September 24, 1958. Since these data were taken from coded reports, the listed temperature and dewpoint values may deviate $0.1^{\circ}$ C. from those shown in the original records.

\begin{tabular}{c|c|c|c}
\hline Height (ft.) & $\begin{array}{c}\text { Pressure } \\
(\mathrm{mb} .)\end{array}$ & $\begin{array}{c}\text { Temperature } \\
\left({ }^{\circ} \mathrm{C} .\right)\end{array}$ & $\begin{array}{c}\text { Dewpoint } \\
\left({ }^{\circ} \mathrm{C} .\right)\end{array}$ \\
\hline & & 27.8 & 26.5 \\
910 & 877 & 26.8 & 24.8 \\
& 850 & 26.2 & 23.5 \\
& 835 & 29.5 & 15.5 \\
6580 & 748 & 27.8 & 14.2 \\
& 700 & 29.8 & 14.2 \\
\hline
\end{tabular}

near $18.9^{\circ} \mathrm{N}$., $135.3^{\circ} \mathrm{E}$., or about 600 miles northwest of Guam. The temperature, dewpoint, and pressure-height data reported in this sounding are shown in table 1 . The temperature varied over a range of less than $4^{\circ} \mathrm{C}$. and the maximum value of $29.8^{\circ} \mathrm{C}$. $\left(86^{\circ} \mathrm{F}\right.$.) was reported at the $700-\mathrm{mb}$. level. The $700-\mathrm{mb}$. surface was reported at $6580 \mathrm{ft}$. and the $850-\mathrm{mb}$. surface at $910 \mathrm{ft}$. above sea level.

In the dropsonde observation the $700-\mathrm{mb}$. height was determined by using the pressure and radio altimeters aboard the aircraft, and the $850-\mathrm{mb}$. height and sea level pressure were computed using the temperature and humidity data measured at flight level by the aircraft instruments and at levels below the aircraft by the dropsonde instrument. The sounding under consideration was found to be hydrostatically consistent and the vertical temperature distribution is realistic, in view of those found in other deep typhoons [3].

The sea level pressure is relatively insensitive to small temperature errors since a relatively thin layer is involved. In fact, an error of $5^{\circ} \mathrm{C}$. at all levels would change the sea level pressure less than $4 \mathrm{mb}$. in the present case. The most likely source of major error in cases of this type is in the aircraft altimetry which provides the beginning point in the pressure-height computation. Errors of this type tend to be systematic for a given aircraft and flight, but are normally small on the reconnaissance aircraft since calibration checks are made as a routine part of each flight. In the case in question, the $700-\mathrm{mb}$. heights reported in the vicinity of Guam are consistent with those given by radiosonde observations. Any systematic error would undoubtedly have been less than $80 \mathrm{ft}$. which would correspond to sea level pressure errors less than $3 \mathrm{mb}$.

Perhaps the strongest supporting evidence of the relia- bility of the dropsonde observation under examination is the fact that another dropsonde observation made about 8 hours earlier from a different aircraft reported a sea level pressure of $878 \mathrm{mb}$. A third dropsonde made about 23 hours later reported a sea level value of $886 \mathrm{mb}$. Since the three dropsonde observations were made from different aircraft, there is little chance that altimetry errors could have been important. Even if the improbable assumptions are made that the aircraft pressure-height values were $150 \mathrm{ft}$. too low and the reported temperatures were $3^{\circ} \mathrm{C}$. too warm at all levels, the soundings made at 2100 GMT, September 23 and 0500 GMT, September 24 would still show sea level pressures lower than the previously accepted record value of $886.7 \mathrm{mb}$.

In view of the evidence cited above, it is felt that typhoon Ida of 1958 should be accepted as the deepest cyclone of record. Typhoons with central pressures as low as those reported in Ida of 1958 are undoubtedly rare. However, there have been at least seven other typhoons in the past eight years in which the minimum sea level pressure was reported to be $900 \mathrm{mb}$. or lower. ${ }^{3}$ It is believed that typhoon Nina of 1953 would qualify as the nearest rival to Ida of 1958 with dropsonde sea level pressures of 886 and $883 \mathrm{mb}$. All of these very deep typhoons have contained extremely strong winds and have covered very large areas. In the case of typhoon Ida of 1958 , the maximum reported $700-\mathrm{mb}$. wind speed was 185 kt. On September 23-24 at the times of the extremely low central pressures, typhoon-force winds were reported both at the surface and $700-\mathrm{mb}$. levels at distances as great as 275 miles from the storm center.

\section{ACKNOWLEDGMENT}

The writer is indebted at Lt. Col. Alexander Kouts of Air Weather Service for directing his attention to typhoon Ida and for providing some of the records used in the preparation of this note.

\section{REFERENCES}

1. R. C. Bundgaard, R. D. Fletcher, and J. R. Smith, "TyphoonEye Cloud Patterns as Viewed from Above," Weatherwise, vol. 12, No. 2, Apr. 1959, pp. 64-66.

2. G. E. Dunn, "Tropical Cyclones," Compendium of Meteorology, American Meteorological Society, Boston, 1951, pp. 887-901.

3. C. L. Jordan, "The Thermal Structure of the Core of Tropical Cyclones," Geophysica, vol. 6, No. 3/4, 1958, pp. 281-297.

3 These were Marge of 1951, Nina of 1953, Ida of 1954, Virginia, Hester and Lola of 1957 , and Grace of 1958 . 